\title{
Punishment as an Inclusionary Practice: Sentencing in a Liberal Constitutional State
}

\author{
ANTJE DU BOIS-PEDAIN
}

The question why the state ought to punish people who have violated certain kinds of norms is one of the oldest concerns of political philosophy. Practices of punishment long preceded the evolution of state authority, and even in contemporary liberal societies some punishment practices persist (quite legitimately) outside state structures, such as the disciplining of children within families. The state's interest in punishing certain norm violations arose from the consolidation of public power, and from the linking of punishment to the overarching task and concern of maintaining public peace. Yet the forms and functions of state punishment have arguably changed significantly since state punishment first became the norm in the late Middle ages. ${ }^{1}$ This is due both to a change in the conception of who we punish, and in our understanding of what we may seek to do by way of punishment. In liberal constitutional states, we think of state punishment as something that the state does on our behalf to an equal, a fellow citizen (used here in the wide sense of someone rightfully present or rightfully living in our society), and moreover someone whose rights are not subject to forfeiture by reason of what he or she has done. ${ }^{2}$ Both of these developments suggest and support a particular conception of state punishment, and more particularly of the sentencing decision: It is a decision that should be understood (in this regard, not unlike parental or familial punishment) as setting the terms of our continued relations with the perpetrator of a crime in light of what he has done.

This chapter puts forward a conceptualisation of the sentencing judgment appropriate for a liberal state: ${ }^{3}$ one that matches the rights-respecting and common weal-oriented

\footnotetext{
${ }^{1}$ Compare the literature cited in notes 8 and 13 below. For an interesting interpretation of the historical material, suggesting that the civilisation of punishment in Europe resulted from an extension to everyone of the respectful treatment originally accorded only to high-status prisoners, see J Q Whitman, Harsh Justice: Criminal Punishment and the Widening Divide between America and Europe (Oxford, Oxford University Press, 2003).

${ }^{2}$ From an historical perspective, see Whitman ibid. From a philosophical perspective, see R A Duff, 'A

Criminal Law for Citizens' (2010) Theoretical Criminology 293; C Brettschneider, 'The Rights of the Guilty. Punishment and Political Theory' in (2007) 35 Political Theory 175.

${ }^{3}$ I use the term 'liberal' to denote a political order that is committed to tolerance and to the protection of individual rights, but whose conception of the common weal includes a broad role for the state in instantiating
} 
foundations of modern state punishment. The criminal law's justification rests on the contribution it makes to upholding the conditions of equal freedom. According equal concern and respect at the sentencing stage means that, notwithstanding the commission of the crime, severance of relations with the offender is not an option. He remains a member of the polity. The task of the sentencing judge is to define how, in our public lives, we move forward from here. A punishment that sets the terms of future relationship is inherently reintegrative. This conception of state punishment places rehabilitation at the centre of a liberal justification of state punishment. Our foundational constitutional commitments also suggest a particular understanding of the proportionality of a penal response: a proportionate punishment is one that has an inclusionary orientation, seeking to respond to the offender not just qua perpetrator of this crime but also as a fellow citizen whose prospects and interests still matter. These commitments are sometimes difficult to sustain in the reality of social relations. But a state committed to equal freedom has no choice but to uphold them.

My argument proceeds in three steps. Part I introduces the term-setting conception of punishment through a critique of standard definitions of state punishment and the example of parental punishment. Acknowledging that it remains an open question whether this reintegrative perspective on punishment fits punishment as practised though our shared public institutions, Part II turns to punishment as practised in the offender-state relationship. Here I set out how state punishment forms an integral aspect of the liberal-constitutional project of upholding the conditions of equal freedom. By drawing on the writings of Johann Gottlieb Fichte, who saw punishment as a 'way back' we offer to each other as members of the same polity, I defend and develop a reintegrative conception of state punishment. What this means for the sentencing decision of the trial court is addressed in Part III of the chapter, where I argue that a constitutionally legitimate proportionality assessment must be 'bifocal' - focused not just on the seriousness of the offending behaviour but also on the question what undergoing the punishment will mean for and do to the offender. Humanity and welfare in sentencing requires that we, the polity, take responsibility for what we do to a person whom we punish. A thicker conception of constitutional proportionality mandates moderate and non-destructive punishment.

and maintaining conditions of life conducive to human security and equal freedom. This notion of liberalism reflects the self-understanding of the liberal welfare states of modern Europe. In its acceptance of a wide remit for legitimate state activity, it is closer to what some writers label 'republicanism' than it is to a libertarian conception of the state. 


\section{The Term-setting Conception of Punishment}

\section{A. The standard definition}

A fairly standard definition of state punishment would highlight the following features of the practice: 1. an intentional infliction of harm or hardship on a person, imposed 2. in order to reproach that person for a criminal wrong that the person is found to have committed 3. by someone entitled to make this wrong his business and to perform the punishing act. ${ }^{4}$

This undoubtedly captures central aspects of state punishment.

First, by classifying the penal sanction as a harm, a form of hard treatment, a setback to the punished person's interests, a deprivation of some of her rights, and so on, the standard definition reminds us of what many consider the main issue in the justification of punishment: that punishing someone involves doing something to the recipient that is typically experienced as unpleasant and that (in a state context) we would otherwise view as a violation of her rights. If what is inflicted on the punished person is not recognisably a setback to (at least) their liberty-based interests in some appreciable way, then we are not dealing with a core case of punishment.

The standard definition, secondly, reminds us of the way in which punishment is necessarily backwards-looking and communicative: It is a response to something the person being punished has done, more specifically a response whose point it is (perhaps among others) to censure the punished individual for what she has done. What is done is an act of reprobation. It signifies that hard treatment is inflicted by reason of the punishee's having behaved badly, and in order to bring it across to her that her earlier behaviour is disapproved of.

Thirdly, the definition makes it clear that the punisher claims for herself a certain kind of standing: in the very act of punishing another, the claim is implicit that one is entitled to make the offender's misbehaviour, and hence his punishment, one's business. Such standing arises from the relationship between punisher and punishee. Given that punishment involves the actual or potential use of force against the punishee (it is not optional for the individual who is being punished to undergo his punishment; he does not undergo it by agreement) this

\footnotetext{
${ }^{4}$ See e g D Boonin, The Problem of Punishment (Cambridge, Cambridge University Press, 2008) Ch 1; H L A Hart, Punishment and Responsibility: Essays in the Philosophy of Law, 2nd edn, edited by J Gardner (Oxford, Oxford University Press, 2008) 5ff; R A Duff, 'Legal Punishment', in E Yalta (ed), Stanford Encyclopedia of Philosophy (revised entry dated 13 May 2013), available at http://plato.stanford.edu/entries/legal-punishment/.
} 
relationship must be asymmetrically structured - in other words, it must be an authority relation: the punished person is subject to the authority of the punishing agent in respect of the behaviour for which punishment is inflicted. ${ }^{5}$

\section{B. A gap in the standard definition?}

For all its strengths, the standard definition misses a pivotal feature of punishment. To see this, it helps to take a step back from state punishment and to enter another very familiar penal setting: parental punishment.

Why do parents sometimes punish their children? What I have in mind here are not trivial occasions where children disobey their parents and suffer mild consequences (such as being deprived of ice cream after failing to heed the parental warning that 'If you don't put that smartphone aside now, you will not get any ice cream for dessert'), but instances of fairly serious misbehaviour - say, when a teenager is found to have taken a not insignificant sum of money from his mother's purse to buy himself a desired item that she refused to buy for him. The mother then faces the uncomfortable realisation that she cannot just let this sort of behaviour go, even though she might feel tempted to do just that. Moreover, she realises that her response must have the features identified by the standard definition of punishment. Why? Because her response will set the terms for her continued future existence with her son, and these terms must be set so as to make it clear to him that this sort of behaviour by him will not be tolerated. Let's imagine that the mother decides that her son will be 'grounded' for four consecutive weekends and that he also has to do household chores such as cleaning the bathroom and the kitchen for her until the value of his cleaning work equals the sum of money he has taken. It will undoubtedly take some effort from her to see this through. What will motivate her to make that effort is the knowledge that she and her son will have to continue to live together and that they cannot do so on terms where he gets away with stealing her money. She needs to establish a durable and satisfactory basis for their future interactions.

The important feature which the parental punishment scenario shares with state punishment, and which the standard definition of punishment merely alludes to by

\footnotetext{
${ }^{5}$ But see L Zaibert, Punishment and Retribution (Aldershot, Ashgate 2006) for a sustained challenge to definitions of punishment that build (state) authority into the definition. Thom Brooks, in his review of Zaibert's book, perceptively points out that on Zaibert's definition, the conceptual distinction between punishment and revenge may be lost, and it becomes more difficult to develop the grounds for normatively distinguishing between legitimate and illegitimate punishment ((2007) 10 New Criminal Law Review 311 at 313-14).
} 
highlighting the reprobative element, is this: Typically, we engage in punishing a person because we assume that a 'life in common" ${ }^{6}$ will somehow have to continue with that person. There is little point in going to the trouble of punishing someone if we will never see them again (though we can, of course, quickly do something to them to 'get even' before they disappear from our lives). Punishment is integral to social practices that teach individuals how to live together. ${ }^{7}$

As a general social practice, then, punishment does not merely mark out the punishee's actions as wrong and blames him for engaging in this wrongful act. It also defines how both punishee and punisher will move forward from here. The penal agent lays down the terms of his or her future co-existence with the offender in a shared social world. Because this is punishment's central social function, there is a re-integrative momentum inherent in punishment that gives the offender himself an interest in being punished. Far from threatening or challenging an offender's membership in the community, punishment reasserts and reinforces it.

\section{Punishment and Exclusion}

But isn't there an obvious challenge to this conceptualisation of the point of our penal practices? Doesn't punishment sometimes consist in the severance of relationship? Isn't permanent exclusion on the cards as something like 'the ultimate sanction', whether in informal, interpersonal or in public and state-administered penal interactions?

Historically it is of course undeniable that some of the things that were done to people by way of sanctioning them for past misbehaviour amounted to their permanent exclusion from their communities. ${ }^{8}$ One of the sharpest punishments practised by Germanic tribes was

\footnotetext{
${ }^{6}$ This is the expression used by Timothy Macklem for a shared communal life governed by norms; see T Macklem, Law and Life in Common (Oxford, Oxford University Press, 2015).

${ }^{7}$ M K Stohr, A Walsh and C Hemmens, Corrections: A Text/Reader (Thousand Oaks, Sage, 2009) 3 summarise the findings of evolutionary biologists as establishing that ' $[\mathrm{p}]$ unishment (referred to as moralistic or retaliatory aggression) ... is an evolutionary stable strategy ... for the emergence and maintenance of cooperative behavior' (original emphases omitted). Psychologists have developed more nuanced accounts of the functions of punishment and reward in education. See generally A Bandura and R H Walters, Social Learning and Personality Development (New York, Holt, Rinhart and Winston, 1963). The 'moral education' theory of punishment developed by J Hampton ('The Moral Education Theory of Punishment' (1984) 13 Philosophy \& Public Affairs 208), by contrast, relies on a normative account of moral education and does not build on sociobiological understandings of punishment.

${ }^{8}$ Sanctions aimed at expelling individuals from communities coexisted with a raft of sanctions that were practised on those expected to remain - mostly, sanctions involving public humiliation, shaming and exposure. For the historical development, see C L von Bar, A History of Continental Criminal Law, translated by T S Bell and others (London, John Murray, 1916) Chs 2 and 4; E Schmidt, Einführung in die Geschichte der deutschen Strafrechtspflege 3rd edn (Göttingen, Vandenhoeck \& Ruprecht, 1965).
} 
to declare the miscreant vogelfrei, literally 'free as a bird' - effectively an outlaw. This declaration rendered him rightless. He mattered no more than a wild animal to which anyone could do what they liked. ${ }^{9}$ In later ages, transportation arguably amounted to something similar to permanent exclusion even though it was often technically imposed for a limited time period, the transported criminal being in theory free after its expiration to return to his home land. ${ }^{10}$ And insofar as the death penalty is still practised its point also appears to be to destroy any possibility of a future life in common - not even the life in common that exists between free members of the polity and those incarcerated in prisons or otherwise institutionalised. ${ }^{11}$

These observations may lead us to doubt that, conceptually, punishment is necessarily a re-integrative institution. The communicative dimension of penal practice reminds us that someone may inflict a response by way of punishment that in effect consists in expelling the individual from the community. While such penal dispositions are unlikely to be (at least in practice) a frequent penal response, they are arguably still recognisably cases of punishment. $^{12}$

A long line of legal historians have, however, defended the view that the difference between expulsion and non-expulsion provides us with the conceptual boundary of punishment, and in developing this point their argument invariably turns on the authority relation that genuine punishment appears to require. Some have stressed that being expelled from a community means that one is no longer under the authority (and, of course, the protection) of the law that governs this community, and that those outside our legal sphere of concern are not fit subjects for the exercise of legal authority over them (since they are not legal subjects) - whereas punishment is centrally the exercise of lawful authority. ${ }^{13}$ At least

\footnotetext{
${ }^{9}$ On outlawry, see von Bar ibid at 62-66 and Schmidt ibid.

${ }^{10}$ On transportation, see J M Beattie, Crime and the Courts in England, 1660-1800 (Oxford, Oxford University Press, 1986) Ch 9; S Devereaux, 'In Place of Death: Transportation, Penal Practices, and the English State, 1770-1830', in C Strange (ed), Qualities of Mercy: Justice, Punishment and Discretion (Vancouver, UBC Press, 1996) Ch 2; C Herrup, 'Punishing Pardon: Some Thoughts on the Origins of Penal Transportation', in S Devereaux and P Griffiths (eds), Penal Practice and Culture, 1500-1900: Punishing the English (Basingstoke, Palgrave Macmillan, 2004) 121.

${ }^{11}$ Even before the humanisation of imprisonment, brought about, inter alia, through prisoner rights litigation, the nature of imprisonment as a regime under which legal relations are continued rather than severed cannot be in doubt. On contemporary relations of imprisonment, see D Van Zyl Smit and S Snacken, Principles of European Prison Law and Policy: Penology and Human Rights (Oxford, Oxford University Press, 2009). On the history of imprisonment, see T Krause, Geschichte des Strafvollzugs. Von den Kerkern des Altertums bis zur Gegenwart (Darmstadt, Primus, 1999).

${ }^{12}$ At least where the motivation behind their infliction is retributive rather than preventive.

${ }^{13}$ See already von Bar, History, above n 8 at 57-66, 71-76, 95ff. For modern analyses, see H Nehlsen,

'Entstehung des öffentlichen Strafrechts bei den germanischen Stämmen', in K Kroeschell (ed), GerichtslaubenVorträge. Freiburger Festkolloquium zum fünfundsiebzigsten Geburtstag von Hans Thieme (Sigmaringen, Jan
} 
in Western Europe, punishment developed as a practice by which one deals with those under one's government - and was thus not how criminal wrongs were dealt with among free men (suggesting that outlawry marked the end of peaceful relations between equals rather than an authoritative exercise of penal power within a hierarchical relationship). ${ }^{14}$

One indication that relationship-severing reactions may indeed mark the conceptual boundary of punishment can be found in the exact message that relationship-severing dispositions send. Arguably, their communicative meaning is not exhausted in the simple message that 'this is what I do to you in response to your crime'. It is, more specifically, that: 'Because of your crime, I wash my hands off you. I will have nothing to do with you any more. I will make no effort on your behalf. The world in which I live no longer includes you.' Relationship-severing reactions thus come across not as punishments but rather as reactions to transgressions we are no longer prepared to punish. ${ }^{15}$ They signify a refusal to affirm the continuation of the relationship by punishing. Recall that punishing a person may require considerable commitment and continuing effort on the part of the punisher, an investment of sorts, something that the punisher must consider worth her while. From the punisher's perspective the effort is worthwhile because it will (in her expectation) re-establish the terms of their communal existence.

Torbecke, 1983) 3. On the evolution of a public criminal law generally, see D Willoweit (ed), Die Entstehung des öffentlichen Strafrechts. Bestandsaufnahme eines europäischen Forschungsproblems (Cologne, Böhlau, 1999); H Schlosser, R Sprandel und D Willoweit (eds), Herrschaftliches Strafen seit dem Hochmittelalter. Formen und Entwicklungsstufen (Cologne, Böhlau, 2002); K Lüderssen (ed), Die Durchsetzung des öffentlichen Strafanspruchs. Systematisierung der Fragestellung (Cologne, Böhlau, 2002); and J Weitzel (ed), Hoheitliches Strafen in der Spätantike und im frühen Mittelalter (Cologne, Böhlau, 2002).

${ }^{14}$ German legal historians have convincingly suggested that outlawry was distinct from state punishment, since outlawry, as Mireille Hildebrandt explains, was practiced between freemen and 'placed [the offender] outside the community of freemen and outside the grasp of its peace' (M Hildebrandt, 'Radbruch on the Origins of the Criminal Law', in M D Dubber (ed), Foundational Texts in Modern Criminal Law (Oxford, Oxford University Press, 2014) 219 at 232). State punishment, by contrast, emerged from the essentially hierarchical and unequal relationship between serfs and their overlords; see G Radbruch, 'Der Ursprung des Strafrechts aus dem Stande der Unfreien', in G Radbruch, Elegantiae Juris Criminalis: Vierzehn Studien zur Geschichte des Strafrechts (Basel, Verlag für Recht und Gesellschaft, 1950) 11, of which Hildebrandt's essay is a fascinating discussion and evaluation. A translation of Radbruch's essay is available at http://www.oup.com/uk/law/foundational-texts. ${ }^{15}$ Hannah Arendt famously suggested that there are crimes of such enormity that we reach a limit to our ability to respond to them meaningfully by way of punishment. She then went on to suggest that, for this reason, we would also reach a conceptual barrier to forgiveness ( $\mathrm{H}$ Arendt, The Human Condition, 2nd edn with an introduction by Margaret Canovan (Chicago and London, University of Chicago Press, 1998) 241). While, with Pumla Gobodo-Madikizela, I doubt that our ability to forgive is conceptually tied to our ability to punish, the question how we should respond to persons who have committed crimes that we feel we simply cannot respond to through a mechanism that offers them a way back, remains both acute and unsolved. For an incisive reflection on Arendt's position, see P Gobodo-Madikizela, 'Radical Forgiveness: Transforming Traumatic Memory beyond Hannah Arendt' in F du Bois and A du Bois-Pedain (eds), Justice and Reconciliation in Post-Apartheid South Africa (Cambridge, Cambridge University Press, 2008) 37. 
The pressing question, then, is whether the term-setting conception of punishment introduced in this section through the analogy of parental punishment provides us with a viable perspective on state punishment. Parental punishment is, after all, quite different from state punishment in that it is (ideally at least) a constructive form of discipline linked to a child's upbringing through parental guidance within the family. That said, as Thorburn rightly stresses in his contribution to this collection, something that parental and state punishment have in common is the relationship of authority from which the penal standing of the punishing agent flows. We must therefore look at the nature of the relationship between members of a polity and its public authority to see whether the term-setting conception of punishment is also applicable to the sentencing judgment of a criminal court. The next Part of this chapter analyses this relationship, arguing that the humanistic and political commitments on which life in a liberal political community is based require a re-integrative conception of punishment that rules out the severance of relationship as a response to crimes.

\section{Punishment and the Offender-State Relationship}

\section{A. State punishment and the conditions of equal freedom}

What is distinctive about modern constitutional states is a certain conception of the rights of members of the populace. Most importantly in the present context, they consist in our guaranteeing to each other the most extensive personal freedom that is compatible with equal freedom exercised by others, and to do so through public institutions that provide equal protection to the (normatively conceived) interests of all. Even if there were no philosophical knock-down argument as to why people have certain fundamental rights, and why these rights (including the right to membership in the polity) should be inalienable, there would be ample grounds for saying that a political order based on the recognition of such rights is preferable to one which is not so structured. This is because an order committed to the recognition and protection of such rights fosters actual security (it does not do to people what would be destructive of their most important interests) as well as perceptions of security (people expect that the actions of those who hold positions of power will not be destructive of their interests). ${ }^{16}$ It is therefore an order in which the answer that can be given to members

\footnotetext{
${ }^{16}$ See also Zedner's chapter in this volume.
} 
who make what Bernard Williams memorably calls the 'basic legitimation demand'17 is likely to be a satisfactory one: 'I exert power over you (among others) because my doing so is in your interest'. ${ }^{18}$

When we think of the criminal law as helping to instantiate and preserve the conditions of equal freedom, we will first focus our minds on how to preserve freedom at the legislative stage. This will give us some guidance as to what behaviours we need to address through criminalisation. But already at this stage we need to be sensitive to the question how an 'order of freedom, 19 would address those whose freedom is to be secured - as moral agents, not as tigers to be controlled. ${ }^{20}$ And - at least to some extent - we will also think about the question how our enforcement mechanisms should, concretely, interact with those we suspect of having violated this order of freedom, and then how they should respond to those who are found to have violated it. But these matters remain rather abstract at the legislative or (from an enforcement perspective) ex ante stage of the criminal law. At this stage, criminal law does the job it is meant to do if it only criminalises behaviour that can be legitimately criminalised as being inimical to the preservation of an order of freedom, and (to the extent that this order is preserved by addressing us as potential law-breakers) by offering us - in form of threats of punishment - an additional prudential disincentive to desist from criminal law-violations. As Andreas von Hirsch has correctly highlighted, this means that not just any punishment can be threatened by the law. The punishment must be measured,

\footnotetext{
${ }^{17}$ See B Williams, In the Beginning was the Deed: Realism and Moralism in Political Argument, edited by G Hawthorn (Princeton NJ, Princeton University Press, 2005) 5. The notion of the 'basic legitimation demand' is interpreted and explored by Bottoms and Tankebe, who explain it as the 'demand by subjects that the powerholder should provide adequate justification of his/her claim to rule' (Bottoms and Tankebe, in this volume). I am grateful to them for drawing my attention to Williams' essay.

${ }^{18}$ This possible answer to the demand remains fairly abstract. What meeting the basic legitimation demand entails concretely in the interactions between representatives of state authority and members of the public, is the focus of Bottoms' and Tankebe's chapter in this collection.

${ }^{19}$ Note that by speaking of an 'order of freedom' or 'the conditions of equal freedom', I do not mean to nail my flag to the mast of any particular political theory of what the preservation of freedom entails, and conversely rules out. Rather I use this phrase here as a placeholder for a convincing account. Personally, I lean towards a Hegelian-inspired (sometimes called republican) understanding that conceives of freedom 'not so much [as] a matter of being left alone as it is "the condition of citizenship in a free society"' (R Dagger, 'Republicanism and Crime', in S Besson and J L Martí (eds), Legal Republicanism: National and International Perspectives (Oxford, Oxford University Press, 2009) 147 at 154 (quoting J Braithwaite and P Pettit, Not Just Deserts: A Republican Theory of Punishment (Oxford, Clarendon Press, 1990) 57)). For a sustained Hegelian account of what makes a free society, see A Honneth, Freedom's Right: The Social Foundations of Democratic Life (Cambridge, Polity Press, 2014).

${ }^{20}$ See A von Hirsch, Censure and Sanctions (Oxford, Oxford University Press, 1993) 13-14.
} 
otherwise it risks drowning out the moral message that is respectful of a legal subject's moral agency and personality even when it is telling the subject what not to do. ${ }^{21}$

Respect for offenders as moral agents matters again - and in a somewhat different way from what we have already set out above - when the criminal law stands to be applied to a particular person in respect of a particular incident. Viewed simply from an ex ante perspective, the criminal law might well restrict itself to conduct rules pure and simple. Effective conduct guidance needs to presuppose, and would therefore import, a certain extent of mens rea considerations - enough to differentiate between agency and non-agency, but no more. $^{22}$ Yet it is generally not doubted that the criminal law should contain rules of evaluation that address a law-breaker's culpability in a more comprehensive sense. ${ }^{23}$ The constitutional reason for wanting blameworthiness and exculpatory defences to matter at the adjudication stage is that relating to each other as moral agents (as opposed to something like harm-causing automatons) requires us to be responsive to the reasoning processes and the motives of the other person - to her culpability, above and beyond the kinds of mental states that made her conduct a token of the exercise of her agential powers in the world. ${ }^{24}$ 'All that matters to me is that you did it; your beliefs, attitudes and motives at the time and the pressures which may have been exerted upon you are irrelevant to me' would be tantamount

\footnotetext{
${ }^{21}$ Ibid. For an interesting challenge to the empirical plausibility of the drowning-out objection to harsh penalties, see M Matravers, 'Is Twenty-first Century Punishment Post-desert?', in M Tonry (ed), Retributivism has a Past. Has it a Future? (Oxford, Oxford University Press, 2011) 30 at 38-39. For a defence of the 'prudential disincentive' perspective on legal sanctions, see Z Hoskins, 'Deterrent Punishment and Respect for Persons' (2011) 8 Ohio State Journal of Criminal Law 369 at 382-84.

${ }^{22}$ For discussion of this point, see Mark Dsouza, A Theory of Rationale-based Defences ( $\mathrm{PhD}$ thesis, University of Cambridge, 2014) Ch 2, drawing on Meir Dan-Cohen's well-known article 'Decision Rules and Conduct Rules: On Acoustic Separation in Criminal Law' (1983-1984) 97 Harvard Law Review 625, where Dan-Cohen distinguishes between conduct rules (addressed to the citizen) and rules of adjudication (addressed to officials). When applied to the criminal law, rules of adjudication are not (as one might otherwise think) only procedural rules. Rather, they include what one might perhaps label 'rules of evaluation' - certain provisions and concepts of the substantive criminal law that tell adjudicators how to evaluate a breach of the criminal law rather than telling a member of the polity prescriptively how to avoid committing a crime. Broadly speaking, substantive rules that go towards the blameworthiness of defendants (giving rise to incapacity or to non-justificatory exculpation) belong to this group.

${ }^{23}$ On these two senses of culpability, see J Dressler, Understanding Criminal Law 6th edn (Albany NY, LexisNexis, 2012) 118-19. For the reasons given in the text, culpability in this wider sense is relevant not just for those who (to paraphrase Douglas Husak) 'dream the retributivist dream'; a point that is overlooked by D Lefkowitz, 'Blame and the Criminal Law' (2015) 6 Jurisprudence 451 in his otherwise very interesting rebuttal of D Shoemaker, 'Blame and Punishment' in D J Coats and N A Tognazzini (eds), Blame: Its Nature and Norms (Oxford, Oxford University Press, 2013) 100.

${ }^{24}$ On the culpability principle and its roots in a commitment to engaging with offenders as moral agents, see $\mathrm{T}$ Hörnle and M D Dubber, Criminal Law: A Comparative Approach (Oxford, Oxford University Press, 2014) 108-9 (quoting a decision by the German Federal Supreme Court, BGHSt2, 194 (200)). For an historical analysis, see S Stübinger, Schuld, Strafrecht und Geschichte. Die Entstehung der Schuldzurechnung in der deutschen Strafrechtshistorie (Cologne, Böhlau, 2000).
} 
to saying 'I refuse to see you and relate to you as a moral agent, I see you and relate to you merely as a cause of harm'. This is a stance we reject in our political constitution.

At the sentencing stage we yet again need to ask the question what our fundamental political commitments mean for how we should go about things at this point. The generalised ex-ante aim of all good governance, to provide a system of rules conducive to human freedom and security, to a well-lived life in common, does not as such provide us with direct guidance as to how state authority should act in the particular, ex-post case of responding to a situation where its ex-ante prohibition has failed to prevail. One of the first philosophers to see this clearly was Johann Gottlieb Fichte, and although his answer is given in the context of a social contract theory that has not attracted many followers, it pays to look at how he sets up and resolves the problem of justifying the infliction of punishment in concrete cases. ${ }^{25}$

Fichte thinks that what obligates people towards each other is a social contract under whose terms they recognise each other as holders of rights. The commission of a crime signifies, for Fichte, that the contract is breached, in consequence of which the contract is terminated and all rights that the offender had under the contract are lost. ${ }^{26}$ This, however, is not the end of the matter, nor is punishment yet anywhere in sight. Building the familiar historical notion of outlawry into his theory, Fichte at this point assumes that the crime pushes relations between the offender and the polity into a state of rightlessness - as our brief discussion in Part I intimated, a perilous situation for the offender since he is no longer connected to others through relations of right and anything might be done to him with impunity. ${ }^{27}$

The interesting step in Fichte's account follows on this. Most of the time, he points out, it is neither in our communal interest nor in the interest of the offender himself that he remains in a condition where no rights are recognised between him and us. Therefore, instead of now simply treating the offender as an outlaw, the state will usually offer him a way back

\footnotetext{
${ }^{25}$ Fichte's discussion of state punishment can be found in $\S 20$ of his Grundlage des Naturrechts nach Principien der Wissenschaftslehre Vol 2 (Jena and Leipzig, Gabler, 1797). I quote here from the English translation: J G Fichte, Foundations of Natural Right According to the Principles of the Wissenschaftslehre, edited by F Neuhouser and translated by M Baur (Cambridge, Cambridge University Press, 2000) 226-48. Fichte's theory of punishment receives a brief but excellent treatment in von Bar, History, above n 8 at $424 \mathrm{ff}$. Valuable recent discussions include A Lazzari, "Eine Fessel, die nicht schmerzt und nicht sehr hindert": Strafrecht (\$20)', in J C Merle (ed), Johann Gottlieb Fichte, Grundlage des Naturrechts (Berlin, AkademieVerlag, 2001) 173 and R Zaczyk, Das Strafrecht in der Rechtslehre J G Fichtes (Berlin, Duncker \& Humblot, 1981).

${ }^{26}$ Fichte ibid at 226.

${ }^{27}$ See esp. Fichte ibid at 241-42. Whatever we may do to a former member of our polity who, through his crime, has forfeited his rights, is not punishment.
} 
- and this way back is through punishment. ${ }^{28}$ State punishment is thus conceived of in terms of an Abbüßungsvertrag ${ }^{29}$ (contract of atonement), from which (as von Bar explains Fichte's argument) "the criminal derives "the important right" that he is not declared absolutely without rights but is to be punished'. ${ }^{30}$ Fichte effectively treats the criminal law itself as a general-anticipatory contract of atonement - in the punishments it threatens (with the immediate purpose of preventing violations of the law), it also anticipates the terms on which a future contract of atonement will be struck. ${ }^{31}$

Fichte's starting point that an offender loses all his rights through the commission of the crime and has to be allowed back and regain his rights through a 'contract of atonement' is not one that we need to accept - in fact, we have to resist it because our foundational political commitment is to accord each other rights that are inalienable, including the right to membership. But the difference this makes is unimportant in the context of the present discussion. What matters here is Fichte's realisation that the purpose we pursue ex ante with a penal prohibition that threatens punishment (to protect our rights as persons living under a social contract) does not carry across to the imposition of punishment. At this point, the deterrent threat of punishment has failed in the individual case, the prudential appeal has not been heeded. If we identify the function of the criminal law at the ex ante stage with (broadly speaking) rights-protection and preventive regulation, then the imposition of punishment does (and must necessarily) serve a different function.

\section{B. The reintegrative orientation of state punishment}

What, then, is the function of the imposition of punishment?

[A]ll citizens promise to all others that they will give them the opportunity to make themselves fit to live in society once again, if in the present they are found to be unfit;

\footnotetext{
${ }^{28}$ Fichte ibid at 227 and 236.

${ }^{29}$ Fichte's own exposition is more complicated, in that he presupposes not one but two contracts of atonement. The first one deals only with offences for which 'expiation by adequate counterpoise' is possible (ibid, 227-29). This contract does not cover any crimes arising from an offender's 'formally bad' will, nor crimes committed directly against the state (236). A second contract of atonement (discussed at 236-40) deals with this much larger group of offences - and this is the contract of atonement to which my discussion in the text relates. ${ }^{30}$ Von Bar, History, above n 8 at 425 (quoting Fichte). Incidentally, it follows from Fichte's position that the death penalty is not a punishment at all, and must be understood rather as something we do to a person who we no longer treat as having any rights and to whom we refuse to offer a contract of atonement. See von Bar ibid. ${ }^{31}$ Note that this right is not absolute, but premised on the ability of the offender to give sufficient assurance that he can 'make [himself] fit to live in society again' - which, Fichte assumes, those guilty of 'intentional, premeditated murder' will be unable to do (Fichte, Natural Right, above n 25 at 241).
} 
and (what is also entailed by this contract) that they will accept them back into society, after they have reformed, ${ }^{32}$

is how Fichte explains the terms of the contract of atonement. Punishment thus aims at the 'political reformation' of the offender, which Fichte defined as 'reform of the manners and maxims of a person's actual behaviour' and 'certainly not the moral reform of one's inner disposition'. ${ }^{33}$ Fichte insists that the time an offender spends in an institution of rehabilitation (which is Fichte's conception of the prison) must be subject to a 'peremptory term for reform, in accordance with his particular crime'. ${ }^{34}$ The overall orientation of punishment towards reformation does not however permit us to set open-ended terms of indefinite punishment, with successful reformation of an offender a condition of his release. Reasonable contractual terms can include the promise that part of the punishment will be waived if things go well. But they cannot consist in saying 'you are going to be punished until at a later time I decide otherwise'.

Fichte's central insight into the nature of state punishment as concerned with an offender's reintegration into the community of the law-abiding, on terms that are (in my reading of Fichte's theory) set within the broad framework provided for by the criminal law and legitimated in the individual case by the offender's ability to provide us with sufficient reassurance of his future law-abidingness, helps us to address the classical freedom-oriented challenge against reformatory punishment: the suggestion that state punishment may not aim to 'better' or 'improve' the criminal. ${ }^{35}$ This challenge is based on a certain conception of what respecting freedom means. We should not interfere with people's lives through the criminal law if all we aim to do is paternalistically to interfere with the way they conduct their lives. Legitimate interference must be directed at conduct that properly concerns other members of the polity because it is conduct that oversteps the boundaries of equal freedom centrally, because it is harmful to others and violates or endangers their rights, or significant communal interests (say, the preservation of the environment, or road safety).

\footnotetext{
${ }^{32}$ Fichte ibid at 236.

${ }^{33}$ Fichte ibid at 237 (emphasis original).

${ }^{34}$ Fichte ibid at 240. Note, however, that for Fichte this 'peremptory term' for reform also functions as a deadline - the offender will be released, indeed, but if unreformed he will be denied re-entry into society and will be excluded from the polity after all. For discussion see Zaczyk, Strafrecht, above n 25 at $115 \mathrm{ff}$.

${ }^{35}$ See, generally, M Matravers, 'Political Neutrality and Punishment' (2013) 7 Criminal Law and Philosophy, 217 at 219, discussing 'possible tensions ... between (impartialist) liberalism and aspects of a system of criminal law and punishment', arising in particular when state penal policies are based on rejecting some conceptions of the good, or on promoting others. Even if punishment does not aim to reform morally but only politically (in Fichte's sense), it clearly aims to inculcate in the offender skills and a work ethic conducive to a different way of life.
} 
But this argument has force mainly at the criminalisation stage. Assuming a properly restrained reach of the criminal law, it is the violation of the conditions of equal freedom that authorises the penal response by the state. What makes this response legitimate, however, is not (again) that it does not set itself a paternalistic objective. Quite the contrary: what legitimates punishment is that the offender is prepared for living in the conditions of equal freedom. A state that respects the basic entitlement of all members of its population to the conditions of equal freedom has a duty to help those of its inhabitants who cannot respect these conditions to acquire the capacity to do so. ${ }^{36}$ And - as Fichte himself clearly sees offenders cannot be prepared for a responsible life in freedom through an experience of animal-like captivity in which their ability to lead a self-directed life is dulled instead of furthered. ${ }^{37} \mathrm{He}$ calls for regimes of imprisonment that further responsible agency by allowing prisoners significant self-governance in prison. ${ }^{38}$ Prison life should thus inculcate the values, dispositions and habits essential for a law-abiding life post-release. ${ }^{39}$

As for the appropriate level of penal severity, Fichte has this to say:

The primary rule in this regard is that one should neither despair of [the prisoners'] reform, nor cause them to despair of it - and furthermore, that they should have some degree of satisfaction with their condition, as well as the hope to improve it. ${ }^{40}$

This view does not commit us to purely reform-oriented punishment across the board. To see this, consider how the duties we have towards young offenders (and the consequent offenderorientation) in the context of youth justice differ from the recognition of an adult offender's non-forfeitable status of equal political membership. As individual human beings, many adult offenders may well be rather similar to young offenders when it comes to social and individual dysfunctionalities that are generative of criminal behaviour. They may have low levels of skills, bad anger control and generally underdeveloped abilities at self-management.

\footnotetext{
${ }^{36}$ Compare E N Yankah, 'Republican Responsibility in Criminal Law' (2015) 9 Criminal Law and Philosophy 457.

${ }^{37}$ Fichte, Natural Right, above n 25 at 240.

${ }^{38}$ Fichte ibid at 239.

${ }^{39}$ A politically reformed offender is one whose 'dissoluteness has been replaced by a love of diligence and order, [his] savagery replaced by a milder sensibility' (Fichte ibid at 240). What Fichte means by this concretely becomes clear from his sketch of reformatory practice discussed in the text: offenders should acquire the skills and habits that give them a stake, and reasonable prospects of self-maintenance, in mainstream society.

${ }^{40}$ Fichte ibid at 238. One should, however, avoid the impression that Fichte offers on this topic what we would nowadays regard as a coherent and fully worked out liberal position. Fichte's own exposition is somewhat meandering and on occasion veers wildly between what modern readers would consider calls to unreasonable harshness and moderate suggestions. Moreover, the steps in the argument are often open to question. Fichte's own vision of constructive prison life (in something akin to an island community of prisoners) betrays a certain degree of disconnection from common sense.
} 
They may also struggle with addiction and with mental illness. There is certainly a line of continuity here (which is also unsurprising, given that many young offenders continue offending into (at least) early adulthood). ${ }^{41}$ Yet the objectives of sentencing - also the communicative objectives - change when we move from youth to adult cases. They change with the community's overall relationship with the offender. What we owe (as a community) to under-age members (whether they have come in conflict with the law or not) is in two important ways defined by that person's status as being under-age: This supplies both a ground and justification for paternalistic intervention, and an obligation to educate and protect. ${ }^{42}$ And it is accepted that doing these things in the interest of young people imposes certain additional burdens on other members of the community - and that it is distributively appropriate that they should be shouldered by the community. It is a shared obligation to help young people get a sufficiently good start in communal life - and to the extent that the young person is failing at that, part of the responsibility for making things right rebounds on those who are generally responsible for helping the young get a reasonable start. It is thus our duty towards the young offender that mandates the educational or reform-orientation of youth justice.

The sense that we have obligations towards offenders does not evaporate when offenders reach adulthood. But the nature and extent of the obligations change. The sentencing judgment speaks to the offender, the victim and the community, and what it communicates are the terms that we - a political community that governs itself under the ideal of equal freedom - believe are appropriate to impose on a member of our polity who has violated the terms of equal freedom. We believe that some hardship is necessary to mark the seriousness of what he has done. Proportionate punishment is therefore the first and foremost objective - it is the way in which we mark the seriousness of the offending conduct (and treat each other as equals in doing so). But we also believe that the offence is not the end

\footnotetext{
${ }^{41}$ See generally A A J Blokland and P Nieuwbeerta, 'Life Course Criminology', in S G Shoham, P Knepper and M Kett (eds), International Handbook of Criminology (Boca Raton, CRC Press, 2010) 51; M Rocque and B C Welsh, 'Offender Rehabilitation from a Maturation/Biosocial Perspective', in M DeLisi and M G Vaughn (eds), Routledge International Handbook of Biosocial Criminology (Abingdon, Routledge, 2015) 501.

${ }^{42}$ Compare e g the German Juvenile Justice Act, s 2 (Aims of the Juvenile Justice System): '(1) The main aim of the application of criminal law to young people is to counter renewed offending by young persons. In order to achieve this goal, procedure and disposals ... shall be chosen primarily with educational objectives in mind.' See also Sentencing Guidelines Council, Overarching Principles: Sentencing Youths: Definitive Guideline (November 2009), para. 1.2: 'When sentencing an offender aged under 18, a court must have regard to: a) the principal aim of the youth justice system (to prevent offending by children and young persons); and b) the welfare of the offender.' See also (with individual contributions analysing juvenile justice policies and policy shifts in various jurisdictions) J Junger-Tas and S H Decker (eds), International Handbook of Juvenile Justice (New York, Springer, 2006).
} 
of relations between us and the offender. Punishment does not sever legal or societal links. The offender is here to stay, and he or she is (at least in principle) also here one day to return to a life in freedom. For that reason, proportionate punishment must also be constructive constructive in the sense that a successful life in freedom must be a real possibility. We must not (as Ashworth once put it) 'de-socialise' the offender, ${ }^{43}$ and we may have to (as Yankah argued) provide active assistance to those who once released would otherwise not stand much of a chance of building law-abiding lives for themselves. ${ }^{44}$

The sentencing decision marks the moment where the criminal law moves from threatening people with certain consequences for breaches of its rules to doing burdensome things to particular individuals who have transgressed these rules anyway. When this stage is reached, the conceptually dominant goal becomes rehabilitation.

To see why this is so, we need to recall what justifies the state in actually punishing an offender: the offender's interest in partaking again in a life in common committed to the preservation of the conditions of equal freedom. His interest in succeeding in such participation - in leading a coercion-free life in the future - provides the justification for a penal imposition that has his reformation as its goal (and realistically possible outcome).

Based on our discussion thus far, more can be said about how this goal may be pursued. Punishments aimed at an offender's personal reform run the risk of overstepping the 'license' given to the state, which is only to preserve conditions of equal freedom, not to make people better people as such. ${ }^{45}$ To place rehabilitation within the license, we have to connect it to the understanding of the sanction as setting out the terms for future existence in a shared social world - conditions bounded by the focus on securing the conditions of equal freedom for all. Rehabilitation is a legitimate goal of the criminal justice system when it is based on acknowledging that it serves the interests of offenders as well, in that it is meant to make it more likely that they will be able to conduct themselves in future as members of society who respect the conditions of equal freedom for all.

The most important aspect of the trial court's sentencing judgment is that, in determining what should happen to an offender in respect of the crime, the judgment holds

\footnotetext{
${ }^{43}$ A Ashworth, 'European Sentencing Traditions: Accepting Divergence or Aiming for Convergence?', in C Tata and N Hutton, Sentencing and Society: International Perspectives (Aldershot, Ashgate 2002).

${ }^{44}$ E N Yankah, 'Republican Responsibility', above n 36 at 473. This is why it is entirely right that liberal constitutions such as the Italian one mandate that the objective of punishment is rehabilitative, and link this to the state's respect for the dignity of offenders.

${ }^{45}$ Compare also A von Hirsch and A Ashworth, Proportionate Sentencing: Exploring the Principles (Oxford, Oxford University Press, 2005) Ch 7 (critiquing the penance perspective developed by Antony Duff).
} 
out the promise that this is what will settle the matter; it defines how we move forward from here. The sentence is part of an interaction that is irreducibly not merely past- but also futureoriented: future-oriented in the sense that it is aimed at creating the conditions under which full equality and full community with the perpetrator is re-established. This conception of the sentencing judgment is the only one appropriate to the criminal justice practices of a constitutional state. In such a state, exclusion is not an option; rights are not forfeitable - they cannot be lost or denied as a consequence of a crime; they can merely be limited or interfered with in certain ways. Legitimate state punishment punishes offenders on the assumption that a way of life that includes both the punisher and the punishee continues for the duration of and also after the punishment - the assumption is one of a shared social world, in which punisher and punishee both remain. If we break the law, terms of atonement must always be offered to us.

\section{Choosing the Sentence: How to Punish Proportionately}

\section{A. Proportionality and individualisation}

If one treats the perspective on the sentencing judgment put forward here as 'the basis of a sentencing system, ${ }^{46}$ then certain parameters emerge as necessary or desirable features of the system. Some leeway to individualise sentences is constitutionally required because the legitimacy of the individual sentence hinges on the defensibility of setting precisely these terms for continued relationship with this perpetrator in respect of this crime. Proportionality and individualisation of punishment are thus hard-wired into the criminal justice practices of states founded on the ideal of equal freedom ${ }^{47}$ - arguably, all modern constitutional states. Far from proportionate and discretion-based sentencing being contrasting ideals potentially in tension with each other, proportionality in sentencing emerges, as one Irish judge put it, as 'the manner in which judicial discretion should, as a matter of principle, be exercised within particular proceedings'. ${ }^{48}$

\footnotetext{
${ }^{46}$ Ashworth, 'European Sentencing Traditions', above n 43.

${ }^{47}$ For judicial recognition of this point, see the jurisprudence of the Supreme Court of Canada, which held in $R v$ Ipeelee; $R$ v Ladue [2012] 1 SCR 433 (SCC) that 'proportionality in sentencing could aptly be described as a principle of fundamental justice under s. 7 of the Charter', and has stressed that the duty of the judge is to 'impose a sentence that both speaks out against the offence and punishes the offender no more than is necessary' ( $R$ v Nasogaluak [2010] 1 SCR 206 (SCC) para 42 (LeBel J)).

${ }^{48}$ Murray CJ in Whelan and Lynch v Minister for Justice, Equality and Law Reform [2007] IESC 34, [2012] 1 IR 1.
} 
This does not however help us much in resolving the question how proportionate sanctions should be identified in particular cases. Lacey and Pickard argue that it is a mistake to think that 'appealing to proportionality as an abstract ideal can deliver limits to punishment'; rather, such limits 'need to be grounded in substantive judgments about fair and proportionate penalties which are meaningful to, and regarded as legitimate by, the populace in whose name they are imposed'. ${ }^{49}$ They are surely right about this. The notion of proportionality as such does not give us much substantive guidance (although it can, and does, supply us with the three-step methodology familiar from constitutional adjudication). We need to know what values and aims underpin the decision we are about to make. ${ }^{50}$

Matravers also believes 'that an entitlement to proportionality in sentencing is not an independent principle, but is - as with all entitlements - determined by the wider theory of justice'. ${ }^{51}$ Regarding the latter, Matravers himself has pursued the connections that may exist between a Rawlsian notion of distributive justice and retributive justice concerns particularly the question whether we can draw a parallel between natural talents and dispositions such as intelligence, discipline, perseverance that Rawlsians understand as supplying no 'desert basis' in distributive justice, and (in our society) unfortunate individual 'constitutions' (dispositions and personality traits) that tend to bring a person in collision with the criminal law. ${ }^{52}$ I want to ask that same question, starting however with a different conceptual framework: the wider theory of justice implicit in a constitutional order founded on equal concern and respect, and on inalienable rights.

Of course, one conclusion has long been drawn explicitly in many a constitutional document: the prohibition of 'unusual or degrading' punishments. But even after we rule out sanctions that humiliate offenders and/or inflict suffering for suffering's sake as violations of

\footnotetext{
${ }^{49} \mathrm{~N}$ Lacey and H Pickard, 'The Chimera of Proportionality: Institutionalising Limits on Punishment in Contemporary Social and Political Systems’ (2015) 78 Modern Law Review 216 at 219.

${ }^{50}$ It is not clear to me that scholars promoting proportionate sentencing would (have reason to) disagree. Andreas von Hirsch explicitly recognises that the anchoring points of any penalty scale are fixed through a political process that is responsive to cultural notions of severity and to political ideals (of which penal leniency may well be one). The overall defensibility of the system is only assured if the anchoring points are set so as not to violate the injunction against threatened sanction levels that strike fear rather than appeal to moral agency. Ordinal proportionality, which involves parity between crimes of comparable seriousness, rank-ordering of types of crimes according to seriousness, and spacing of penal responses so as to reflect these different degrees of seriousness, operates within this cardinal setting. (See von Hirsch, Censure and Sanctions, above n 20 at 12 19 and 36-46.) To my mind, then, in von Hirsch's model proportionality is (quite in line with what Lacey and Pickard ibid call for) precisely not 'a naturally existing relationship, but a product of political and social construction, cultural meaning-making, and institution-building'.

${ }^{51}$ Matravers, 'Twenty-first Century Punishment', above n 21 at 42 (original emphases omitted).

${ }^{52}$ M Matravers, 'Mad, Bad, or Faulty? Desert in Distributive and Retributive Justice' in C Knight and Z Stemplowska (eds), Responsibility and Distributive Justice (Oxford, Oxford University Press, 2011) 136.
} 
our constitutional order, we still have to confront the question how heavily the human interests and prospects of the person we punish should weigh with us in deciding upon their punishment. Do we have a warrant - perhaps even an obligation - to look any further than the seriousness of the offending behaviour (its gravity and the offender's degree of culpability) in determining the severity of the response? In some jurisdictions the courts have taken this stance. Irish courts have long stressed that '[s]entences must be proportionate first of all to the crime but also to the personal circumstances of the offender', because ' $t$ t]he accused person has a constitutional right which guarantees that his trial [does] not shut out a sentence appropriate to his degree of guilt and relevant personal circumstances'. ${ }^{53}$ In Canada, one commentator recently concluded that the constitutional jurisprudence on sentencing has arrived at a point where

it would now be an error ... for a judge to speak of proportionality without emphasizing the individualized nature of the sentencing process and then wrestling with the real effects of the criminal process and proposed sentence on the life lived by the offender. ${ }^{54}$

In this section, I want to defend this 'bifocal' proportionality assessment, where the sentencer must (as part of her task of setting reasonable terms for re-entry) look not just at the gravity of the offending behaviour, but also consider the effect of the contemplated punishment on the offender considered as a socially embedded human being. Unlike others who defend this position, I will not base my argument on giving mercy (or some other concept employed to loosen the strictures of a purely deeds-based sentencing approach) its due. $^{55}$ My position is a different one: A constitutionally legitimate proportionality assessment, I argue, must include considerations pertaining to the person of the offender, above and beyond what matters to an assessment of his culpability in respect of the crime. This argument relies on two interconnected constitutional values - humanity and welfare.

\footnotetext{
53 See, e g The State (Healy) v Donoghue [1976] IR 325 (Henchy J); The People (Attorney General) $v$ O'Driscoll (1972) 1 Frewen 351 (Walsh J), The People (DPP) v M [1994] 3 IR 306 (Denham J); Director of Public Prosecutions $v$ Stephen Kelly, judgment of 5 July 2004 (CA) (unreported) (Hardiman J); Pudliszewski v Judge Coughlan [2006] IEHC 304 (MacMenamin J).

${ }^{54}$ B L Berger, 'Sentencing and the Salience of Pain and Hope' (2015) 70 Supreme Court Law Review 337 at 361. For a review of developments in the case law, see also M-E Sylvestre, 'The (Re)Discovery of the Proportionality Principle in Sentencing in Ipeelee: Constitutionalization and the Emergence of Collective Responsibility' (2013) 63 Supreme Court Law Review 461.

${ }^{55}$ See, e g, J Tasioulas, 'Punishment and Repentance' (2006) 81 Philosophy 279; B van Stokkom, 'Tempering Justice with Compassion: Rationales of Personal Mitigation in Sentencing' in D J Cornwell, J Blad and M Wright (eds), Civilising Criminal Justice: An International Restorative Agenda for Penal Reform (Sherfield-onLoddon, Waterside Press, 2013) 255.
} 


\section{B. Humanity and welfare in sentencing}

If punishment responds to what this person has done, that also means that it responds to this person who has done it. Refusing to see this person as a full, three-dimensional, human being with a biography and a future would be to disregard and thereby disrespect his humanity. Such a shutting out of questions concerning who it is we punish - treating him as entirely defined (for our purposes) by the crime he has committed and the mindset with which he committed it - would be a kind of disrespect. By considering how a sentence will affect a convicted person's life more generally, a sentencer shows that she is prepared to treat the offender as a potential source of value - not just of 'intrinsic value' as a human being, but as importantly connected to others - of value as a socially embedded agent who cares about, and is cared about, by other people, for reasons pertaining to him and how he leads his life if one casts one's eye wider than the crime. In other words, she does not reduce the person to the crime. Ideally, perceiving the offender concretely as a socially embedded individual whose existence brings value to some other people's lives, will push the sentencer towards a better understanding of how the sanction she has in mind to impose will affect that person, and she will make an effort to avoid gratuitous infliction of harm. ${ }^{56}$ Sentencing is also a human interaction. Once the 'you' is seen more clearly for who he is, the question 'what should I do to you' becomes more arduous. Proportionality as

an intrinsically individualized concept ... denies escape to the comfort of cool metrics and abstract guidelines for the judge faced with the harrowing moment of intervening in the shape of an individual's life through the infliction of suffering. Ethically, that is as it should be, because this demand for sympathetic engagement with the particular person standing before the court invites modesty and caution about the use and effects of state violence as a response to social breakdown. ${ }^{57}$

As the sentencer understands better what is at stake for the person being sentenced, moral responsibility for the sentence can no longer be hived off to the impersonal command of the law that authorises the decision. ${ }^{58}$

\footnotetext{
${ }^{56}$ On the risk that such human emotions may also backfire against particular offenders, and the consequent need to have sentencers who are self-aware and calm enough to control against their own visceral reactions of disgust and contempt, see J Q Whitman, 'Making Happy Punishers' (2004-2005) 118 Harvard Law Review 2698 at 2713-14, 2020 and 2023-24.

${ }^{57}$ Berger, 'Sentencing', above n 54 at 361.

${ }^{58}$ A similar point is made by Whitman, 'Making Happy Punishers', above n 56 at 2713 and by H Müller-Dietz, 'Probleme der Strafzumessung - Sanktionsauswahl, -bemessung, Prognose' in E Wadle (ed), Recht und Gesetz im Dialog (Cologne, Carl Heymanns, 1982) 43 at 76.
} 
For some, such individualisation of sentencing decisions is itself a cause for worry. What is at the heart of this worry has perhaps been captured best in Thorburn's defence of a 'strong proportionality principle' - the term coined by Michael Tonry ${ }^{59}$ for the proportionate sentencing model developed and defended by Andreas von Hirsch and Andrew Ashworth ${ }^{60}$ over a 'limiting retributivism' that allows sentencers to take different sentencing goals into account in shaping the outcome of their decision. Thorburn asserts that desert-based sentencing 'ties the structure of judicial reasoning in the process of determining sentences to the grounds of the state's role in imposing criminal punishment ${ }^{61}$ in that it keeps the sentencing judge within the bounds of considerations it is constitutionally appropriate for a sentencing judge to engage in: it ensures that the judge will 'provide the right sort of justification for the sentence she imposes in the particular case' ${ }^{62}$

Thorburn's objection to inviting judges to consider the life history and personal characteristics of the offender, and to adjust a sentence in light of how the judge expects the sanction to affect the future life course of the offender, rests on a divergence between state punishment and parental punishment when it comes to 'the normative ground of the authority the punisher holds over the punishee'. ${ }^{63}$ Whereas 'parents are legitimately charged with ensuring the welfare of their children, broadly understood', the remit of the state's authority over the individual citizen qua offender is both 'different in kind and much narrower in scope'. ${ }^{64}$ By implication this appears to exclude a welfare orientation from state punishment, given that welfare-oriented decision-making presupposes a legitimately paternalistic stance which, in turn, only exists when the grounds of authority are essentially fiduciary in nature.

There is considerable truth in that contrast. Yet it becomes in my view overdrawn when it appears to rule out a welfare-oriented dimension to state-imposed punishment. Thorburn is sensitive to this, hinting that it might be possible to justify 'deviat[ions] from the proportionate sentence on grounds of rehabilitation ... [as] part of a larger argument

\footnotetext{
${ }^{59}$ M Tonry, 'Proportionality, Parsimony and Interchangeability of Punishments' in RA Duff, S E Marshall, R E Dobash and R P Dobash (eds), Penal Theory and Practice (Manchester, Manchester University Press, 1994).

${ }^{60}$ For von Hirsch's classic account, see his Censure and Sanctions, above n 20 and the later and fuller treatment together with A Ashworth, in von Hirsch and Ashworth, Proportionate Sentencing, above n 45.

${ }^{61}$ M Thorburn, 'Proportionate Sentencing and the Rule of Law', in L Zedner and J Roberts (eds), Principles and Values in Criminal Law and Criminal Justice: Essays in Honour of Andrew Ashworth (Oxford, Oxford University Press, 2012) 269 at 271.

${ }^{62}$ Ibid at 271 (emphasis added) Note that, like von Hirsch and Ashworth, Thorburn does not mean to rule out judges ever responding to other considerations pertaining to the interests of an offender. His view is merely that the sentencing judge 'must give proportionality what Rawls calls 'lexical priority', which leaves 'some (very limited) room for sentencing judges to consider other factors' (ibid).

${ }^{63}$ Ibid at 283.

${ }^{64}$ Ibid at 283-84.
} 
concerning the necessary conditions for ensuring the independence of the offender'. ${ }^{65} \mathrm{My}$ main argument here is that we should not think of rehabilitative considerations as leading to 'deviations' from a punishment that would otherwise be warranted at all - instead, we should recognise that considerations concerning the offender's humanity and personal interests are integral to the notion of proportionate punishment in the constitutional state.

Our fundamental constitutional values commit us to treating each other as creatures of intrinsic value. This gives rise to a concern for the welfare of every member of the polity. At the most general level, this commits us to shaping our institutions of public life such that they will not be harmful or disadvantageous to individual members of the polity but will rather help them in leading productive and fulfilling lives.

Insofar as we act with a welfare orientation, we treat fellow members of the polity as entitled to a certain degree of support simply because they are fellow citizens, and not because of any factors about them as individuals that make them particularly deserving of support. Thus, we do not make access to healthcare conditional upon a person having done nothing to put their own health at risk: we treat mountain climbers, smokers, drinkers, drug addicts, and the sexually adventurous, just like everyone else. This is not, I take it, because we wouldn't be prepared to judge such behaviours morally (and, in the context of such moral judgment, disapprove of some behaviours on the basis that the person not only lets herself down, but indirectly us as well, given that we promised to provide each other with a certain level of basic services without enquiring whether a person's need to access these services was avoidable or not, and that they knew this as well as we do). Of course, part of the reason why we refrain from allowing such moral judgments to register in our public settings of access to services is the practical concern that it would be very difficult to make such judgments reliably. But the larger part of the reason pertains to our political morality - we think that the kind of society in which access to basic social support depends on judgments of individual moral deservingness is one that imports too much personal moral judgment into the public domain, which is ultimately not conducive to our common good.

This is not a commitment that evaporates when a member of the polity commits a crime. The welfare orientation of all state action must also register in how we design our criminal justice system. The offender remains a member of this polity, and a concern with his legitimate interests - including the interest to one day to return to a common life in freedom -

65 Ibid at 284. 
is integral to what may be done to him by way of state-imposed punishment. ${ }^{66}$ In short, constitutionally appropriate sentencing considerations must seek to assess not just culpabilityrelated matters but also the reality of this offender being made subject to this punishment.

If I am right, we are now in a position to see why Thorburn is wrong to assert that strong proportionality is the only position compatible with the grounds of state authority. The state's authority partly rests on its commitment to welfare - this does not give it an entitlement to 'forge ahead making people better in their own interest' but it does need to be factored into how we run our penal system - and if we do so, responsiveness of the system to the person of the offender becomes a necessity.

\section{Towards a thick conception of constitutional proportionality in sentencing}

The view I defend reflects sentencing principles that are widely accepted and practised elsewhere as well. ${ }^{67}$ What makes the Irish courts' position noteworthy is that what I have described as a 'bifocal' approach to proportionate sentencing is drawn directly from the constitution, and while the judgments do not spell out from which specific provisions in the Irish constitution this interpretation is drawn, it is at least plausible that some notion of the state's concern for the humanity and welfare of each member of the polity underlies it. ${ }^{68}$

The Irish courts' approach leads to a thicker notion of 'constitutional disproportionality' than the traditional approaches to constitutionally disproportionate punishment, where it is the extreme disconnection between the overall severity of the penal response and the gravity of the underlying crime that drives the investigation. ${ }^{69}$ It also pushes

\footnotetext{
${ }^{66}$ This duty is recognised (as an upshot of the state's basic welfare obligation towards each citizen) in German constitutional law; for discussion, see T Hörnle, 'Strafzumessungslehre im Lichte des Grundgesetzes', in E Schumann (ed), Das strafende Gesetz im sozialen Rechtsstaat (Berlin, De Gruyter, 2010) 105 at $124 \mathrm{ff}$.

${ }^{67}$ See e g the German Criminal Code, s 46 (Principles of sentencing): '(1) The guilt of the offender is the basis for sentencing. The effects which the sentence can be expected to have on the offender's future life in society shall be taken into account. (2) When sentencing the court shall weigh the circumstances in favour of and against the offender.' [A list of aggravating and mitigating considerations follows, which includes not just crime-related factors but also reference to 'the offender's prior history', 'his personal and financial circumstances', 'his conduct after the offence, particularly his efforts to make restitution for the harm caused as well as the offender's efforts at reconciliation with the victim'.]

${ }^{68}$ In Canada, the courts have nestled their proportionate sentencing jurisprudence under section 7 of the Canadian Charter of Rights and Freedoms (protecting the right to life, liberty and security of the person and permitting infringements only in accordance with 'the principles of fundamental justice'). See M-E Sylvestre, 'The (Re)Discovery of the Proportionality Principle', above n 54 at 464ff. .

${ }^{69}$ I discuss the limitations of a 'classic' understanding of constitutional disproportionality in sentencing in A du Bois-Pedain, 'The Place of Criminal Law Theory in the Constitutional State', in A P Simester, A du BoisPedain and U Neumann (eds), Liberal Criminal Theory: Essays for Andreas von Hirsch (Oxford: Hart Publishing, 2014) 305 at 310-13 and 317ff.
} 
sentencing outcomes towards moderation. By accepting that the punishment, quite independently of the severity of the offending behaviour to which it is a response, also has to be proportionate to 'the personal circumstances of the offender', it links proportionality with respect for the humanity of the offender. It recognises the value of the offender's life in a substantive rather than a merely formal sense. But perhaps the most important implication of the injunction to consider whether the sentence is appropriate not only to the offender's 'degree of guilt' but also to his 'relevant personal circumstances ${ }^{, 70}$ is that we have to consider the effects of the imposition of punishment on the offender as a human individual as something that we have to take responsibility for when punishing him, and not simply as something that we can, indeed should, shrug off with a 'he brought it all upon himself'.

Earlier in this chapter I mentioned Matravers' exploration of a Rawlsian approach to retributive justice. Matravers observes that:

The tendency to act aggressively, and the tendency to work hard, are not only 'influenced by ... natural abilities and skills', but are also both related to certain kinds of outcomes only because of arbitrary circumstances that converted one into an advantage and the other into a handicap. ${ }^{71}$

Extending the benefit of a constitutional welfare commitment also to offenders is one way of making concrete 'Rawls' vision of justice as an agreement "to share each other's fates" Matravers emphasising that 'the reasons we have to endorse prejusticial egalitarianism apply equally to the retributive case' ${ }^{72}$ This is not, Matravers stresses, because individual offenders are not responsible for their actions. They are. Holding people to account for their violations of our order of equal freedom is quite compatible with recognising that living one's life successfully on the terms set by that order is harder for some than for others, and that this in itself gives us reason to consider only a welfare-oriented criminal law distributively just.

The practical import of the stance I take varies with the overall level of sanction severity prevalent in a given penal system. The humanistic proportionality approach endorsed by the Irish courts makes a real difference when compared to deed-proportionate approaches in sentencing systems which resort with greater frequency to sanctions with inherently destructive effects on the lives of those who undergo them for significant periods of time. The significance of the contrast I have drawn here between a sentencing decision that is

\footnotetext{
${ }^{70}$ See the case citations given above at $\mathrm{n} 53$.

${ }^{71}$ Matravers, 'Mad, Bad, or Faulty?', above n 52 at 149 (quoting Rawls).

72 Ibid (again quoting Rawls).
} 
responsive in its own right to what a particular sanction will do to an offender as a person, to his selfhood and life prospects more generally, and a sentencing decision that restricts its attention (except in exceptional cases) to an effort to respond to the gravity of the offending behaviour under sentence, will fade as sanctions themselves become less fearsome and destructive. In penal systems where curfews, weekend imprisonment, electronic monitoring, open prisons and the like are standard ways of serving even fairly long prison sentences, the offender still has ways of engaging in 'almost normal' personal and work relationships. These types of restrictions on the offender's free movement are, unlike traditional confinement in prison, pared down to their pure freedom-restricting effects. They do not restrict life-chances to a degree comparable with traditional incarceration. In such a sanctioning system judges will have less cause to be troubled by the effects that a sanction will have on the person of the offender - as these effects are unlikely to be destructive of the life prospects of released offenders. Against the backdrop of sanctions that are in themselves already moderated compared to present levels of penal severity, apportioning punishment on along the lines advocated by von Hirsch and Ashworth will lead to much the same result as an explicit instruction to judges to consider how the punishment imposed will affect the punishee as a human being. But we should not forget how far many penal systems are from such a situation. $^{73}$

It ought to be clear now that the re-integrative conception of the criminal court's judgment does not demand that judges be given an almost unfettered sentencing discretion. Setting appropriate terms for a polity's continued relations with the perpetrator, as a practical task and a normative ideal, does not require the absence of any restrictions on the court's ability to carve out a response. The perspective on the trial court's sentencing judgment developed here is intended to give shape and unity to the court's task by identifying the overarching framework of assumptions and purposes in which this task is necessarily performed. The model I defend differs from both of the two main scholarly positions on the exercise of sentencing discretion, limiting retributivism and desert-based sentencing. Against limiting retributivism, it maintains that the sentencing stage of criminal justice must be oriented towards one particular goal pursued by criminal justice systems over others: the goal of re-integration. It is not open to sentencing judges to pursue what are in effect policies of

\footnotetext{
${ }^{73}$ Compare the analysis of the effects of imprisonment in J Jacobs, 'From Bad to Worse: Crime, Incarceration, and the Self-Wounding of Society', in S Farrall et al (eds), Justice and Penal Reform: Re-shaping the Penal Landscape (Abingdon, Routledge, 2016) 3 at 23ff (warning against the 'erosion of agential capacities' through contemporary imprisonment regimes, especially but not only in the United States). On 'supermax' prisons, see esp Z Hoskins, 'Punishment, Contempt, and the Prospect of Moral Reform' (2013) 32 Criminal Justice Ethics 1.
} 
deterrence of certain kinds of conduct (of which the defendant's crime is taken to be a typical instance) by imposing a heavier sentence on a defendant than they otherwise would. Against desert-based sentencing, it argues that the sentencing decision legitimately should - indeed, must - consider the person of the offender and his situatedness in the social world (his subjectivity) quite apart from his mental state and other criteria going to his blameworthiness when he was committing his crime. Such attention to the offender's social self is not incompatible with proportionate sentencing practices. To the contrary: this is how, in a sentencing system oriented towards re-integration for the very same constitutional reason that animates proportionality, the constitutional promise to treat each other with respect for our humanity and welfare can be fulfilled.

There is, of course, a possible wide divide between the normative ideal of being a criminal defendant (and later convicted offender) whose entitlement to equal concern and respect as a fellow member of the polity is acknowledged throughout, and the lived reality of being a criminal defendant and later a convicted offender. The real terms of interaction may well be status-reducing, dignity-sapping and expressive of a perception that the punished individual is less than equal and not entitled to full citizenship rights. This can be true both for the legal regimes that govern individuals with some types of criminal records (collateral consequences of conviction, post-release reporting duties and reduced privacy protections are cases in point ${ }^{74}$ ) and of informal social consequences of, particularly, prolonged periods of imprisonment - the de-socialising effects of prison being well known and researched. ${ }^{75}$

Two further points should be made in this regard, though. Firstly, the normative ideal of equal membership in the polity can (and already does) inform critiques and reform efforts directed at current penal realities, whether these strive to replace imprisonment with alternative sanctions or to reform imprisonment such that it avoids alienation and desocialisation. ${ }^{76}$ Secondly, we must distinguish between commitments we make in our political constitutions about how we will relate to each other through the powerful institutions of collective self-governance, on the one hand, and how we interact with each other in our private social encounters, on the other hand. Notwithstanding that the line between public and private matters is difficult to draw (employment discrimination against ex-convicts being a case in point), there is a difference between upholding the normative political ideal of equal

\footnotetext{
${ }^{74}$ See, e g Z Hoskins, 'Ex-offender Restrictions' (2014) 31 Journal of Applied Philosophy 33.

${ }^{75} \mathrm{See}$, e g S Besemer and J Murray, 'Prison as an Environmental Pathogen', in M DeLisi and M G Vaughn (eds), Routledge International Handbook of Biosocial Criminology (Abingdon, Routledge, 2015) 622.

${ }^{76}$ See e g H Müller-Dietz, Menschenwürde und Strafvollzug (Berlin, De Gruyter, 1994),
} 
freedom and the moral ideal of treating everyone with equal concern and respect in our interactions as private individuals. It is not illegitimate in our private lives to seek to distinguish between persons by their differing moral worth, nor is it the point of our political constitution to disallow people from doing that. In this sense, the promise of treating each other with equal concern and respect will always be partial. ${ }^{77}$ It binds us only in the part of our lives that is structured through our public political institutions. It is a personal choice for each one how far we commit ourselves to living according to that ideal also in our private lives.

A generally non-re-integrative, exclusion-based vision of criminal justice is, however, not one by which our criminal justice system can claim to implement the basic commitments on which our political constitution is founded. Assuming that the ideology which informs the penal practices of modern constitutional states rests on the inclusionary, rights-respecting vision of political membership and limited power that I have developed in this chapter, questions can and must be asked about the legitimacy of 'life-thrashing sanctions' of which very long terms of imprisonment and whole-life sentences imposed to meet punitive objectives alone are pertinent examples. If our entitlement to punish each other for criminal wrongs through our collectively created penal institutions is, as I have argued, grounded in a non-negotiable commitment to equal concern and respect premised on equally non-negotiable membership, and if - as I have also argued - we are for this reason committed to a reintegrative conception of state punishment, then some punishments are so obviously destructive that, qua punishments, they are beyond this account of legitimation.

\section{Conclusion}

A penal system needs what Loader has called 'a coherent public philosophy - a story about why and whom, and how and how much, "we" punish that connects with, and re-articulates, sentiments that have some purchase within ... society'. ${ }^{78}$ When examining the legitimacy of trial justice, Henham similarly claims that we need to focus 'on the extent to which sentencing outcomes reflect a "shared morality" about the appropriateness of punishment and

\footnotetext{
77 This not to deny that the boundary between public and private morality is blurry here in another way. If people generally 'maintain hostile, unsupportive attitudes' to released offenders that betray their 'unwillingness to adopt a civil disposition' towards them (Jacobs, 'From Bad to Worse', above n 73 at 24), one's personal refusal to engage with an ex-prisoner may amount to participating in a 'public culture' of rejection such that one's actions stand to be assessed under our public morality.

${ }^{78}$ I Loader, 'For Penal Moderation: Notes Towards a Public Philosophy of Punishment' (2010) 14 Theoretical Criminology 349 at 351.
} 
its impact'. ${ }^{79}$ What I suggest here is that this 'shared morality' is not a shared conception of punishment but a shared vision of legitimate public authority - a constitutionally grounded vision of how we must treat and what we may and may not do to each other.

This vision of political morality might well be a contested one. Hutton observes that one reason why sentencers are increasingly exposed to negative press reaction and to political intervention in sentencing through mandatory sentencing laws appears to be a weakening of the 'social justice paradigm' that underpinned, among other things, trust in judges as representatives of a societal interest common to all - what Garland (whom Hutton cites) has called 'the ideas and values of the solidarity project which emerged in the postwar years' ${ }^{80}$ One consequence may be that 'the public may no longer be convinced by the discourse of justice used by courts', giving rise to a 'need for a "replacement discourse" for sentencing'. ${ }^{81}$ This connects to Lacey and Pickard's hypothesis that 'contemporary societies which have managed to sustain stable limits to punishment have done so ... through institutions and attitudes that foster reconciliatory dispositions between citizens', and to their further claim that "cultural and institutional arrangements which foster high "Associational Value" - in other words, greater expected benefits of continued cooperation between individuals and groups - also foster reconciliatory dispositions' ${ }^{82}$ For Lacey and Pickard, societies that invest heavily in the education and skills development of their members will be more reluctant than others to render such members unproductive - hence their preference for shorter sentences and for non-incapacitating sanctions. ${ }^{83}$

The replacement discourse that is suggested by the conception of the sentencing decision that I put forward in this chapter reminds the public of the offender's common membership in this political community; of the reasons why such membership ought not to be forfeitable, and why exclusion from the shared social world is not a coherent objective of punishment. It is true, of course, that even this commitment may crumble, that societies stop believing in extending recognition and rights to all. But loudmouthed calls for extreme punishments are often made in the abstract, with the recipient of such punishment being conveniently imagined as less than human. When 'criminals are viewed as recognizable members of the community ... and the criminal acts portrayed are more mundane, the kinds

\footnotetext{
${ }^{79}$ R Henham, Sentencing and the Legitimacy of Trial Justice (London, Routledge, 2012) 97.

${ }^{80} \mathrm{~N}$ Hutton, 'Reflections', in Tata and Hutton, Sentencing and Society, n 43 above, 575 at 585.

${ }^{81}$ Hutton, ibid.

${ }^{82}$ Lacey and Pickard, 'The Chimera of Proportionality', above n 49 at 221.

${ }^{83}$ Ibid at 234-37.
} 
of things respondents might imagine themselves doing in certain circumstances, an alternative discourse about the nature of crime and punishment becomes possible' ${ }^{84}$

My sense is that penal moderation may not so much emerge as a quasi-automatic upshot from empirical conditions of high associational value as that it requires associational commitment, a political commitment towards continued association - which, in turn, can be read as a commitment to a (possibly counterfactual) assumption of high associational value. That said, it may be true that for this political commitment to be upheld, Lacey and Pickard are right to suggest that 'the key to penal moderation lies not only in reintegrative criminal justice policy, but in social policy and in political arrangements and institutional structures which maximise expected Associational Value among citizens' ${ }^{85}$

\footnotetext{
${ }^{84}$ B K Crew et al, 'Crisis and Contradictions in a State Sentencing Structure', in Tata and Hutton, Sentencing and Society, n 43 above, 184-85.

${ }^{85}$ Lacey and Pickard, 'The Chimera of Proportionality', above n 49 at 239.
} 